\title{
Measuring the Performance of the Kuwaiti Banking Sector Before and After the Recent Financial Crisis
}

\author{
Atyeh $\mathrm{MH}^{1 *}$, Yasin $\mathrm{J}^{2}$ and Khatib $\mathrm{AM}^{1}$ \\ ${ }^{1}$ School of Business, Australian College of Kuwait \\ ${ }^{2}$ School of Business, Australian College of Kuwait
}

\begin{abstract}
The objective of this research is to investigate the determinants of the performance of the Kuwaiti banking sector before and after the recent financial crisis over the period of 2006-2012. The data utilized is based on the yearly financial statements of the Kuwaiti banks that are listed on Kuwait Stock Exchange over the same period. There are several methods have been used to identify the determinants which impact the performance of the banking sector. In this research, a ratio analysis technique is considered efficient and more reliable method than other approaches. Other factors such as trend, government regulations and other economic factors are also included. The study found that the overall banking sector performance increased considerably in the first two years of the analysis. A significant change in trend is noticed at the onset of the global financial crisis in September 2008, reaching its peak before the global financial crisis. This resulted in decreasing the profitability, return on equity, assets and capital.
\end{abstract}

Keywords: Banking sector; Financial performance; Financial ratios; Interest spread rate; Kuwait stock exchange (KSE); Growth ratios; Financial crisis

\section{Introduction}

The banking industry in general is an old industry and it is one the major factors behind the development of the countries' economies due to the contribution that it provides to the countries and societies.

In Kuwait the banking sector is different than the banking sectors in other countries. The banking sector in Kuwait is considered one of the major sectors that are contributing to the Kuwaiti economy. The banks in Kuwait are divided into two categories which are the traditional banks and the Islamic banks.

The study will be based on the yearly financial statements of all the Kuwaiti listed banks form (2006-2012) except Warba Bank which will be excluded due to the unavailability of its data since it's a newly established bank.

The performance measurement of the banking sector will include an analysis for some internal factors that have a direct affect on the banking sector performance in Kuwait such as the interest rates and the financial ratios. Other factors will be considered such as external factors will be considered such as the growth rates and the Kuwait stock Exchange (KSE) movements during that period since the banks that are included in this research are all listed on the KSE.

Our main source of data and financial information are the Kuwait Stock Exchange website, banks websites and Zawya research in addition to the available market news and information.

\section{Literature Review}

In light of the change in the economic, market conditions and new management needs, banks started to work on improving their capabilities to measure their performance after the recent financial crisis that took place in 2008

Measuring the performance of the banking sector in general is related to many factors that directly affect this kind of institutions. One of these factors is the cost management which requires a better management. Other factor is about managing the relationship with the clients which requires a deeper relationship, in addition to the pricing decisions and its appropriation to the market.

Many scholars have discussed measuring the performance of the banking sector tools and devices such as Tarawneh et al. [1-5]. Measuring the performance of the banking sector topic has received high attention by the researchers over the previous years [6]. However, little research has been done on measuring the banks performance in the gulf region in general and Kuwait in particular.

Some researchers have discussed the banking institutions performance and focused mainly on the cost efficiency and the key performance indicators. However, Isik et al. and Berger et al. in their study believe that looking on both profit efficiency and cost would lead to a more accurate results than focusing on the cost efficiency only $[7,8]$.

The literature on measuring the banks performance shows that the accounting indicators are the main tools such as the profitability and cost financial ratios [5]. However, other researchers have criticized using these accounting tools to measure the performance and recommended using other approaches such as Berger and Humphrey [9].

Many scholars from many countries have implemented the performance indicators method to measure the banks performance, whilst other researchers suggest that the use of these indicators could lead to incorrect results. Some of the researchers that criticized the previous method are Marginson from Australia, Barnett from the United Kingdom [10,11].

Modell and Vakkuri et al. in their research recommend using the financial performance indicators due to the importance of the results that it would lead to. De Kool and Weick confirm the conclusion of the

*Corresponding author: Dr. Atyeh MH, Assistant Professor, School of Business, Australian College of Kuwait, Tel: 1828225; E-mail: m.atyeh@ack.edu.kw

Received November 09, 2015; Accepted November 17, 2015; Published November 30, 2015

Citation: Atyeh MH, Yasin J, Khatib AM (2015) Measuring the Performance of the Kuwaiti Banking Sector Before and After the Recent Financial Crisis. J Bus Fin Aff 4: 156. doi:10.4172/2167-0234.1000156

Copyright: ( 2015 Atyeh MH, et al. This is an open-access article distributed under the terms of the Creative Commons Attribution License, which permits unrestricted use, distribution, and reproduction in any medium, provided the original author and source are credited. 
previous two studies and add that this measurement tool makes sense and a good management method [12-15].

Samad examined the performance of the banking sector in Bahrain and used the financial ratios of seven commercial banks over the period from 1994 to 2001[16]. The performance of these banks was compared to Bahrain banking sector which was considered as a benchmark. The study results indicate that these commercial banks are less liquid, less profitable with a high credit risk.

\section{Methodology}

This paper uses the ratio analysis approach to examine the performance of the banking sector in Kuwait. The study relies on the financial statements of the past seven years from 2006 till 2012 for the banks that are listed on Kuwait stock exchange.

This research paper is different than other studies in in two things they are the methodology and the sample coverage. The methodology used in this research is the ratio analysis method considering the banking industry financials for the period after 2009 financial crisis until 2012 and compared to the period before the financial crisis, 2006 to 2008 .

Using the ratio analysis method to measure the performance of the banking industry shows clearly the effect of the recent 2008 subprime breakdown on the banking industry and identifies the banking sector weaknesses and strengths [16].

\section{Data and descriptive statistics}

The number of observations for each bank is 7 observations while the total number observations are estimated to be 63 observations are shown in Table 1.

\section{Results and Discussion}

Below are the average major financial ratios of the banking sector in Kuwait for the period between 2006 and 2008 (before the financial crisis) and the period between 2009 and 2012 (after the financial crisis) (Table 2).

\section{Financial ratios}

Return on Assets (ROA) is an indicator of how profitable the company is relative to its total assets. Moreover, it gives an idea of how the management is using its assets efficiently to generate profits. In our case, the banking sector seems to be having a stable ROA rate of $1 \%$ between year 2006- 2008 (before the financial crisis) and 2009- 2012 (after the financial crisis).

Return on Equity (ROE) is the amount of net income returned as a percentage of shareholders equity. In addition, it measures the banking sector profitability by revealing how much profit the bank generates with the money shareholders have invested. The Table above shows that the ROE during the period from 2006 till 2008 (before the financial crisis) was $14 \%$ while the period after the financial crisis between 2009 and 2012.

Concerning the Return on Capital (ROC), it measures the returns of the Banking sector as a percentage of its capital. Therefore, ROC in years 2009 till 2012 has witnessed a decrease by $18 \%$ if we compare to the period before the financial crisis.

Net Profit Margin (NPM) indicates how the company effectively is controlling the cost and expenses whether it was operating or nonoperating expenses. In our case the banking sector profitability seems to be decreased by nearly the half after the recent financial crisis, $23 \%$ if we compare to $46 \%$ before the financial crisis period.

Spread in Interest Rare (SIR) is the difference between the average of the interest received and interest paid by the banks. The net interest rate spread is a key determinant of the banking sector profitability. I our case, the average SIR decreased after the financial crisis by $1 \%$ to become 4\% (2009-2012) after it was 5\% (2006-2008).

\section{Growth ratios}

The table below shows the growth percentages of the major indicators for both periods 2006-2008 (before the financial crisis) and 2009-2012 (after the financial crisis) (Table 3).

It is clear from the figures above that the recent financial crisis has affected the performance of the banking sector in Kuwait negatively. Through looking at the major financial ratios for the two periods mentioned, we conclude that the average growth in total assets was decreased to $7 \%$ after it was $20 \%$ in the period before the crisis. Regarding the total liabilities, it seems to be decreased as well to $6 \%$ after it was $22 \%$. While growth ratio of total equity was increased to $12 \%$ after it was $5 \%$. In terms of the net income, and due to the decrease in the banking sector profits that we have seen above, the growth rate I income seems to be decreased by $6 \%$ if we compare the income growth rates of the two periods.

The Figure 1 shows that the movement of the Kuwait Stock Exchange (KSE) index over the period tested in the study from year 2006 till 2012. It is clear that the KSE index sharply declined in September 2008 which is the beginning of the financial crisis. Hence,

\begin{tabular}{|l|l|l|l|}
\hline$\#$ & Bank Name & Ticker & Observations \\
\hline 1 & National Bank of Kuwait & NBK & 7 \\
\hline 2 & Gulf Bank of Kuwait & GBK & 7 \\
\hline 3 & Commercial Bank of Kuwait & CBK & 7 \\
\hline 4 & Ahli Bank of Kuwait & ABK & 7 \\
\hline 5 & Kuwait International Bank & KIB & 7 \\
\hline 6 & Burgan Bank & BURG & 7 \\
\hline 7 & Kuwait Finance Bank & KFH & 7 \\
\hline 8 & Boubyan Bank & BOUBYAN & 7 \\
\hline 9 & Ahli United Bank & AUB & 7 \\
\hline No. of Obs. & & & $\mathbf{6 3}$ \\
\hline
\end{tabular}

Table 1: Number of Observations for Each Bank.

\begin{tabular}{|l|l|l|l|}
\hline Ratios & $\begin{array}{l}\text { Average } \\
\mathbf{2 0 0 9 - 2 0 1 2}\end{array}$ & Ratios & $\begin{array}{l}\text { Average } \\
\mathbf{2 0 0 6 - 2 0 0 8}\end{array}$ \\
\hline Interest Received & $5 \%$ & Interest Received & $8 \%$ \\
\hline Interest Paid & $2 \%$ & Interest Paid & $2 \%$ \\
\hline Spread in Interest Rate & $4 \%$ & Spread in Interest Rate & $5 \%$ \\
\hline Return on Assets & $1 \%$ & Return on Assets & $1 \%$ \\
\hline Return on Equity & $5 \%$ & Return on Equity & $14 \%$ \\
\hline Return on Capital & $24 \%$ & Return on Capital & $42 \%$ \\
\hline Net Profit Margin & $23 \%$ & Net Profit Margin & $46 \%$ \\
\hline
\end{tabular}

Table 2: Average Major Financial Ratios Of The Banking Sector.

\begin{tabular}{|l|l|l|l|}
\hline Growth Rates & Average 2009-2012 & Growth Rates & Average 2006-2007 \\
\hline Total Assets & $7 \%$ & Total Assets & $20 \%$ \\
\hline Total Liabilities & $6 \%$ & Total Liabilities & $22 \%$ \\
\hline Total Equity & $12 \%$ & Total Equity & $5 \%$ \\
\hline Net Income & $-16 \%$ & Net Income & $-22 \%$ \\
\hline
\end{tabular}

Table: 3 Growth percentages of the major Indicators. 
Citation: Atyeh MH, Yasin J, Khatib AM (2015) Measuring the Performance of the Kuwaiti Banking Sector Before and After the Recent Financial Crisis. J Bus Fin Aff 4: 156. doi:10.4172/2167-0234.1000156

Page 3 of 3

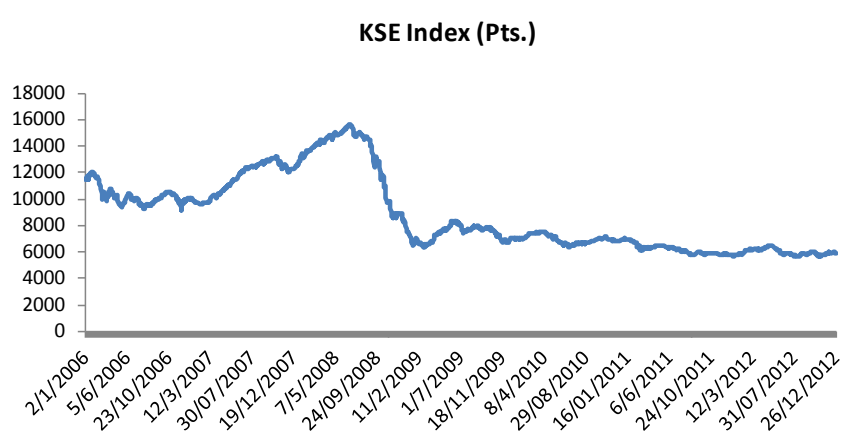

Figure 1: The Movement of The Kuwait Stock Exchange.

we conclude that the Kuwaiti banking sector performance is moving in parallel with the movement of the KSE index which is directly effect by the global market.

\section{Summary and Conclusion}

This research paper measured the performance of Kuwait banking sector over the period between year 2006 to 2012 to include the effects of September 2008 financial crisis.

The results indicate that the overall banking sector performance in terms of profitability, capital, equity and assets has been declined since September 2008 up to 2012 as the banks' operating environment deteriorated due to the global financial crisis and a slowing economy.

Despite these alarming features, Kuwaiti banks have managed to continue with their normal day to day business during the global financial crisis. Kuwaiti banks' low leverage and profitability allowed them to remain liquid and well-capitalized; avoiding any need for extraordinary liquidity or government support.

\section{References}

1. Tarawneh M (2006) A Comparison of Financial Performance in the Banking Sector: Some Evidence from Omani Commercial Banks. International Research Journal of Finance and Economics 3: 103-112.
2. Halkos G, Salamouris D (2004) Efficiency measurement of the Greek commercial banks with the use of financial ratios: a data envelope analysis approach. Management Accounting Research 15: 201-224.

3. Webb RM (2003) Levels of efficiency in UK retail banks: a DEA window analysis. International Journal of the Economics of Business 10: 305-322.

4. Lacewell SK (2003) Do Efficient Institutions Score Well Using Ratio Analysis? An Examination of Commercial Banks in The 1990s. Journal of Commercial Banking and Finance 2: 17-33.

5. Yeh QJ (1996) The Application of Data Envelopment Analysis in Conjunction with Financial Ratios for Bank Performance Evaluation. Journal of the Operational Research Society 47: 980-988.

6. Seiford LM, Zhu J (1999) Profitability and Marketability of the Top 55 U.S. Commercial Banks Management Science 45: 1270-1288.

7. Isik I, Hassan MK (2002) Cost and Profit Efficiency of the Turkish Banking Industry: An Empirical Investigation. The Financial Review 37: 257-280.

8. Berger AN, Mester LB (1997) Inside the black box: What explains differences in the efficiencies of financial institutions? Journal of Banking and Finance 21: 895-947.

9. Berger AN, Humphrey DB (1997) Efficiency of financial institutions: International survey and directions for future research. European Journal of Operational Research 98: 175-212.

10. Marginson $S$ (1995) Universities and the new perpetual motion. Campus Review 5: 8-9.

11. Barnett R (1992) Improving Higher Education: Total Quality Care. Buckingham: The

12. Society for Research into Higher Education and Open University Press 26: 472-475.

13. Modell S (2004) Performance measurement myths in the public sector: A research note. Financial Accountability and Management 20: 39-55.

14. Vakkuri J, Meklin P (2006) Ambiguity in performance measurement: a theoretical approach to organisational uses of performance measurement. Financial Accountability and Management 22: 235-250.

15. De Kool D (2004) Monitoring and utilization: surveillance, struggle, symbol or source of inspiration, Conference of the European Group of Public Administration. 1-4 September, Ljubljana, Slovenia.

16. Weick KE (1995) Sense making in Organizations. Sage: Thousand Oaks, CA.

17. Samad A (2004) Bahrain Commercial Bank's Performance during 1994-2001. Credit and Financial Management Review 10: 33-40. 